\title{
K POJETÍ ZLOČINNOSTI V HYPERMODERNÍ SPOLEČNOSTI
}

\author{
JIŘI BURIÁNEK
}

Je vskutku těžké uvést následující text ${ }^{1)}$ výstižným titulem, nebot' hodláme pojednat nejen téma zločinnosti, ale také trestání, a to nejen ve společnosti naší, která spíše dohání modernizační trend, ale též ve společnostech západního typu. Protože si nejsme zcela jisti, zda již můžeme reálně definovat onen bod (shift), kde lze při analýze doby bez rozpaků užít označení postmoderní, dáváme přednost charakteristice zkoumaného fenoménu jako atributu hypermodernosti (srovnej A. Giddens 1990, D. Garland 1995). Nemyslíme si však, že hloubku analýzy zachrání myticko-rituální zacházení s pojmy modernity či postmoderny (srovnej J. Alexander 1994, J.Šubrt 1996).

Uvažujeme-li o projevech a o strategiích řešení jednoho $z$ nejožehavějších a vpravdě globálních problémů současnosti, dotýkáme se velmi praktických, ba navýsost politických motivů. Chceme se však zabývat také reflexí problému v širších souvislostech, což vyžaduje vpravdě akademický nadhled, skepsi a toleranci. Někdy je to více než obtižné, což svého času velmi sarkasticky komentoval představitel tzv. pravicového realismu v USA James Q. Wilson: „Ovšem poté, co byly mnoha př́slušníkům liberálního tábora ukradeny $\mathrm{v} 70$. letech psací stroje, bylo těžké psát články popírající existenci vlny kriminality“ (Wilson 1975: 83-4). Naším cílem je využít zatím naštěstí přiznivé situace, pokud jde o elementární vybavení pracovními pomůckami, $\mathrm{k}$ přehledovému zmapování současných přístupi̊, které zcela přirozeně oscilují mezi sociálněinženýrským a reflexivně konstruktivistickým úhlem pohledu.

Lze mít za paradoxní, že zatímco právě moderní společnost nabídla člověku alternativy a postavila ho do situace volby, postmoderní uvažování je tu snad nejvíce právě od toho, aby tuto s jistými riziky spojenou okolnost důrazně připomínalo. Sociologie pak - na rozdíl od prístup úzce kriminologických nebo dokonce právnických disponuje znalostí mechanismu převrácených důsledků jednání a zdá se, že sice s menší pompou, ba s jakýmsi reaktivním komplexem méněcennosti, přsto však velmi užitečně upozorňuje (sama sebe!) na riziko produkce falešných očekávání (Keller 1995).

\footnotetext{
1) Stat' využivá materiálu shromážděného s podporou grantů GAČR 403/95/0186 a GA UK č. 186/95, $\mathrm{v}$ jejichž rámci se formovala jako jejich širši teoreticko-metodologický rámec. Nĕkteré z myšlenek byly využity i ve zprávě o plnění grantu MVČR č. 2/96 (viz Buriánek 1997).
} 
Legitimitu spojení konceptu modernity a zločinnosti zdůvodňují - svým způsobem se značným časovým zpožděním - Foucaultovy úvahy o historické provázanosti vzniku moderního státu a novodobých věznic (Blomberg a Cohen 1995). Nejpřesvědčivěji arcit' promlouvají statistiky většiny vyspělých zemí: takřka všude je možno vysledovat postupný růst zločinnosti, a to prakticky kontinuálně od konce 2 . světové války. Po jejím skončení se zdálo snadné vysvětlit tento trend odkazem na anomickou situaci, jenomže ani postupný přechod západních zemí $\mathrm{k}$,welfare state“ nezamezil paralelnímu růstu kriminality. Ani likvidace nejkřiklavější chudoby, ani zmírnění relativní deprivace, ba ani aktivní postup státu nedokázaly tento problém vyřešit: vzniklý stav bezradnosti bývá proto označován jako „etiologická krize“, jako „propadák sociálněpolitického intervencionismu“ (Young 1994: 72).

$\mathrm{K}$ tomu dodejme, že totalitní systémy samozřejmě tak dramatický vývoj nevykazovaly, jejich vývoj po roce 1989 však podobné tendence rychle odbrzdil. Probíhající akcelerovaná (re)modernizace činí všechny historické zkušenosti velmi aktuálními, at' již vezmeme v potaz anomickou porevoluční situaci nebo prohlubující se sociální nerovnost spojenou s riziky relativní sociální deprivace.

Nepřekvapuje př́iliš, že také u nás se při hodnocení více než trojnásobného nárůstu zaznamenané kriminality mezi lety 1989 a 1993, po níž následovalo období stabilizace zhruba na nově dosažené úrovni, zpochybňovala validita získaného obrazu (viz obr. 1). Je známo, že došlo $\mathrm{k}$ dílčím změnám klasifikace trestných činů, leckteré ovšem zcela zmizely. Lze dále spekulovat o tom, do jaké míry se zlepšila důvěra lidí v policii, což by mohlo ovlivnit počet hlášených případů, a do jaké míry sama policie ve snaze vylepšit image úspěšnosti dokázala $v$ minulosti (ale stejně tak dnes) „odrazovat“ občany od hlášení drobných a těžko řešitelných př́ípadů. Tyto jevy se objevují všude na světě, nicméně sotva mohou stát za tak nápadnými změnami.

\section{Obr. 1}

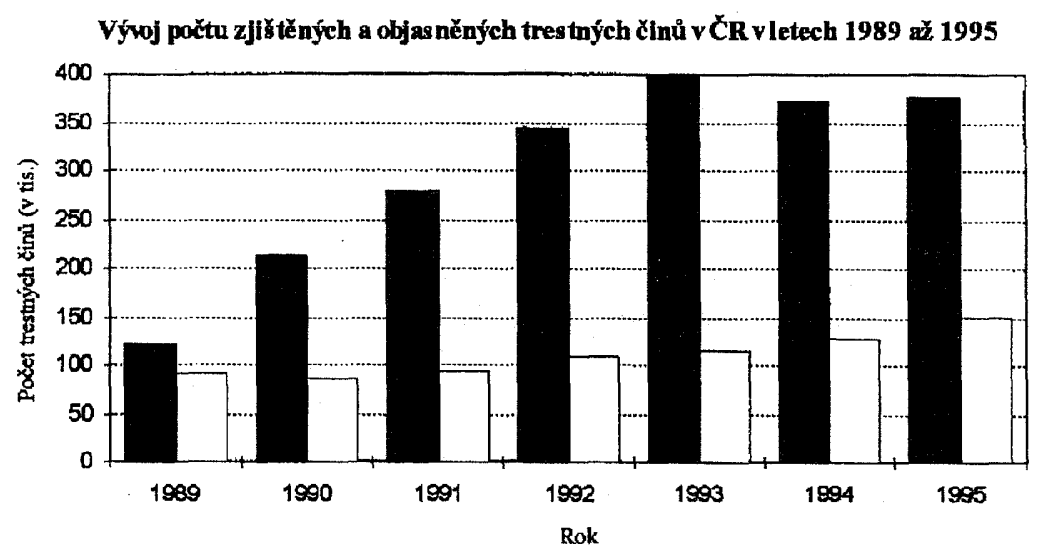

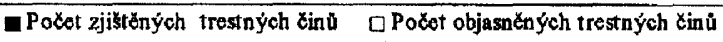


Frustrace spojené s problémem kriminality vedly ve světě už v prüběhu 60 . let ke dvěma možným způsobům reagování. Formu únikovou představovala kritika statistik, jako by ony produkovaly jakýsi falešný obraz skutečnosti, která údajnè tak dramatická není. Zdánlivě se tím aktualizovaly prastaré úvahy A. Queteleta o stabilních proporcích zločinnosti, problém se tak trochu relativizoval a „smetl ze stolu“ (což samozřejmě neznamenalo sejmutí břemena odpovědnosti z přislušných státních institucí). Druhý směr se snažil jednak revitalizovat či dokonce přehodnotit teoretické přistupy, jednak je zároveň vztáhnout $\mathrm{k}$ praktické bezpečnostni politice, korigovat ji či zefektivnit. To prineslo fenomén, kerý by bylo možno předběžně označit jako praxeologizaci kriminologického diskurzu. Z historického hlediska šlo o jakýsi navvrat k predlombrosovskému (předpozitivistickému) modelu rozvoje, kdy vědecké bádání bylo úzce propojeno se státní politikou. Neznamená to, že by byly opuštěny či zapomenuty klasické sociologické teorie anomie a sociální deviace (jmenujme jen letmo E. Durkheima, chicagskou školu, R. K. Mertona, E. H. Sutherlanda, teorie subkultury či labelingu). Ty většinou i nadále vstupovaly do hledání nových, účinnějších politik prevence a trestání. Snaha o důslednější zhodnocení (evaluaci) zaváděných opatření či celých koncepcí samozřejmě podporovala kritické myšlení: proto se i v kriminologickém diskurzu objevily leckdy poněkud kontroverzní postmoderní motivy (Foucault 1977). Ani ty však nemůžeme považovat za apraktickou, rezignující nebo čistě reflexivní variantu uvažování o zločinu.

Cílem našeho dalšího výkladu proto bude shrnout a osvětlit právě tyto nové teoretické impulzy, které se objevily v posledních zhruba třiceti letech. I když vznikly primárně v kontextu vývoje západních zemí, nabízejí určité metodologické možnosti př́stupu $\mathrm{k}$ situaci onoho velkého skoku či třesku charakterizujícího proměny bezpečnostní situace u nás. Rozčleníme je na tři okruhy, které se postupně objevily na scéně a které dodnes vedou jakýsi skrytý dialog:

- metodologický konstruktivismus, zakládající nové pojetí deviace a také kritiku statistik,

- nová kriminologie jako impulz $\mathrm{k}$ řešení sporu pravicové a levicové politiky a konfliktu mezi „idealismem“" a „realismem“,

- reflexivní postmoderním konstruktivismem ovlivněná kriminologie, hledající nové alternativy trestní politiky.

Zmíněné vnitřní pnutí samozřejmě vychází z rozporu mezi sociálněinženýrským př́stupem, který praktická politika př́mo předpokládá, a po výtce kritickoreflexivním pojetím. Předběžně můžeme poukázat na zajímavou otázku, proč v britské kriminologii převažuje spiše praxeologický úhel pohledu, zatímco v USA pozorujeme větší vliv postmoderní reflexe a hledání zcela nových alternativ. Základní vysvětlení může vycházet $\mathrm{z}$ přece jen odlišné míry zločinnosti, která je v USA mnohem vyšší: $\mathrm{k}$ tomu ovšem připojuje J. Young (ale i někteří američtí sociologové, jako např. T. Chiricos) názor, že relativní sociální deprivace (jako latentní přičina zločinnosti) bývá vyšší tam, kde politický systém nenabízi skutečně alternativní formu politiky, kde např. pravicová orientace nepodléhá čas od času sociálnědemokratické korekci. 
Ostatně právě z těchto důvodů je vhodné mluvit o praxeologizaci diskurzu, avšak s vědomím, že současná kriminologie není (naštěstí!) kolbištěm zjednodušujících ideologických schémat a že naprostá většina badatelů bojuje aktivně a odpovědně proti politizaci složitých témat, jakými jsou např. trest smrti nebo náměty typu „třikrát a dost“. Jak řikají T. Blomberg a S. Cohen, není těžké pochopit mimořádný „politický význam zločinnosti v americké společnosti: ve veřejných rozpravách o obavě a nejistotě, $\mathrm{v}$ prijímání nových zákonů, $\mathrm{v}$ politické symbióze mezi odmítáním (resentment) a punitivitou (punitiveness), $\mathrm{v}$ masivních přesunech rozpočtů, $\mathrm{v}$ ovlivňování volebních výsledkü“ (Blomberg a Cohen 1995: 8-9).

\section{Konstruktivismus a kritika statistik}

Konstruktivismus pro nás neznamená zvláštní směr (srovnej Kabele 1996), ale spíše styl myšlení, nebo přesněji argumentace charakterizující interpretativní paradigma. V teorii sociální deviace se objevuje ve dvou podobách:

- teoretické (jako meritorní vysvětlení vzniku deviantního jednání)

- metodologické (coby kritika tradičního pozitivistického přístupu).

Je tudíž vlastní především etnometodologii, přičemž její paradigmaticky fundamentální práce H. Garfinkela a A. Cicourela předbíhá Beckerova kniha Outsiders (1963), klasické již dílo historie teorie sociální deviace. Právě u $\mathrm{H}$. Beckera (a podobně u J. Kitsuse) se objevuje myšlenka, že deviace je vląstně konstruována skupinou či společností, že vzniká jakŏ označení, nálepka (label). Jueho lapidámí př́klad ř́ká, že ten, kdo krade, nemusí být zlodějem, a naopak. Tím razí cestu postmoderně. Jde o expozici pro nás jistě srozumitelnou, připomeneme-li si dvojznačnost Mertonova konceptu inovace, pokud jde o legitimitu používaných prostředků.

Podle anglického kriminologa Colina Sumnera etnometodologický směr (označovaný též jako etiketizační teorie) uzavírá periodu let 1941-67, pro niž volí název Regulating deviance: fantasies of social control (Sumner 1994). Jiní jej považují za východisko zásadní změny paradigmatu (Maguire 1994: 241). Beckerovy kvalitativní studie o uživatelích drog samozřejmě nemohly poprít rozmach analyzovaného jevu, problematizovaly však ryze represivní prístup, zdůrazňující sociální kontrolu, a stimulovaly hledání nových úhlů pohledu. Obdobnou roli sehrály i Goffmanovy studie o stigmatu (1963) a o fungování „totálních instituci“.

Etnometodologická kritika tradičního konceptu měření je u nás již dostatečně známa (Petrusek 1993, Buriánek 1994). V situaci oné zmíněné již etiologické krize nabídla zneklidněným kriminologům elegantně jednoduché řešení: prohlásit statistiky za byrokratické konstrukce, které odrážejí spiše dílči zájmy jednotlivých skupin aktérü. Tento způsob kritiky ưredních statistik ovšem nebyl výsadou pouze interpretativní sociologie - uchylovali se $\mathrm{k}$ němu i někteři príznivci radikální kriminologie (Quinney, Gordon, Chambliss) směřující k neomarxismu (P. Gilroy, St. Hall).

$\mathrm{Na}$ druhé straně je třeba uvést, že ne všichni radikální kriminologové zpochybňovali statistiky a empirické výzkumné metody standardního typu. $Z$ obou těchto myš- 
lenkových zdrojů těžila nakonec i tzv. nová kriminologie, jejíž nástup byl signalizován stejnojmennou knihou v roce 1973 (I. Taylor, P. Walton, J. Young). Také ona vystupovala ostře proti bagatelizaci statistik a zpochybňování alarmujících trendů vývoje.

Připomeňme si alespoň stručně skutečnosti, které se staly koncem 60 . let předmětem zmíněného sporu, kdy napríklad P. Wiles (1971, podle Maguire 1994: 242) prohlašoval, že statistiky explanaci neumožňují, ale spíše ji samy vyžadují. V Británii se v letech 1951-71 zvýšily reálné př́jmy obyvatelstva o $64 \%$, počet zaznamenaných zločinů o $172 \%$ (Young 1994). K podobným závěrům dospěl v 60 . letech v USA J. Q. Wilson. Někteří autoři přitom považují právě druhou polovinu šedesátých let za významné a destabilizující období protestů a občanské neposlušnosti (v USA reakce na vietnamskou válku či rasové konflikty otevírající otázky societální exkluze v jakémsi velkém ghettu), ačkoli počet trestaných i obavy veřejnosti ze zločinnosti ještě několik let předtím nedávaly di̊vod k neklidu (Skolnick 1995: 20).

S uvedenými námitkami, že reálná prevalence kriminality je jiná, než jak uvádějí statistiky, se musela vyrovnat světová kriminologie zejména ve zmíněném období etiologické krize. Optimisté uváděli následující argumenty proti burcujícímu obrazu nadměrného růstu kriminality:

- policie je stále úspěšnější v odhalování zločinu,

- stále dokonalejší právní regulace „způsobuje“ větší počet přestupků zákona,

- občané jsou citlivější a častěji události hlásí,

- rozvoj životní úrovně a životního stylu vytvárí více príležitostí pro potenciální pachatele.

Realisté kladli důraz na to, jak se mění tolerance na straně policie i veřejnosti a jak se vyvíji úroveň sociální kontroly. Pesimisté ovšem připomínali existenci oné „temné figury" nezaznamenané kriminality a hledali dalši cesty jak zpřesnit odhady. Následný vývoj dal za pravdu spíše těm, kteř́ viděli důvod $\mathrm{k}$ obavám.

\section{Obr. 2}

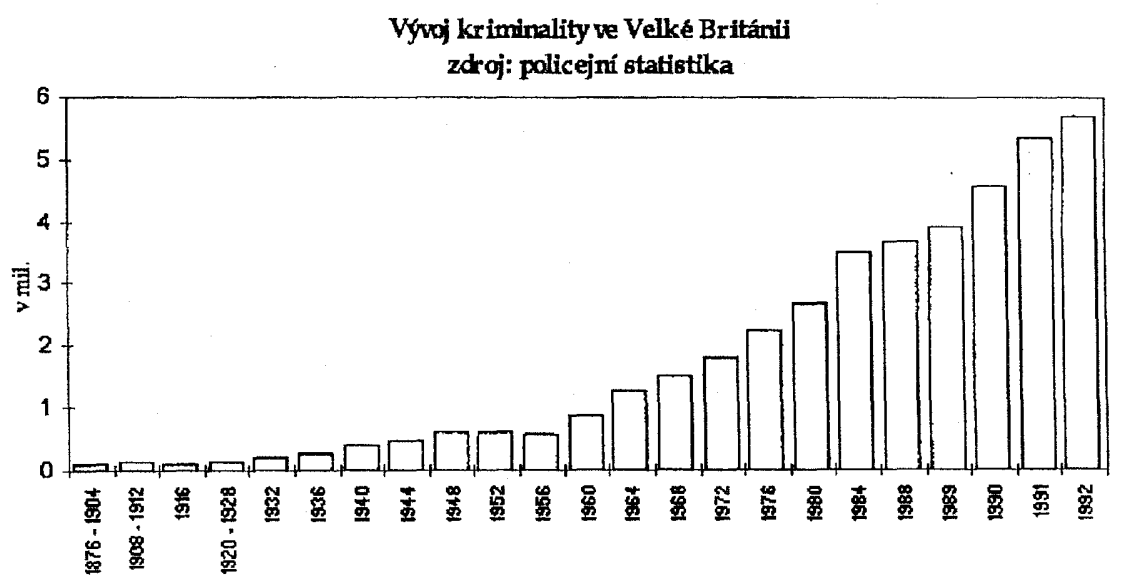


Obavy pesimistů potvrzují i nejnovější oficiální britské údaje (Maguire 1994). Další růst kriminality v 70 . a 80 . letech způsobil, že v porovnání s rokem 1950 se poměr 1 trestný čin na 100 obyvatel změnil na $10,6 / 100$ v roce 1992 . Neznamená to, že údaje tohoto typu jsou stoprocentně přesné: také v Anglii se např. měnila nejnižší hranice pro hlášení škody, platí zásada jeden čin = jeden pachatel, i když často jde o celé série (typické např. pro defraudace). Na tomto místě se však nebudeme zabývat detaily - pro srovnání se situací u nás postačí uvést celkový graf vývoje v Anglii dokonce od roku 1876 (viz obr.2 - údaje ministerstva vnitra 1993 uvádí Maguire 1994: 258).

Je logické, že rostou také náklady na boj se zločinností: v rozmezi let 1981-91 stoupl v Británii počet policisti̊ o $6,3 \%$, civilních pracovníki̊ u bezpečnosti o $24 \%$, př̌čemž v téže době vzrostla zločinnost o $94 \%$, počet nouzových volání o $72 \%$ a počet aut na silnicích o $38 \%$. Tendenci ke zprísnění trestu (v souvislosti s charakterem delikti̊) přibližuje také následující tabulka.

Tab. 1 - Složeni vězněných v Anglii podle délky uložených trestů

\begin{tabular}{|lrr|}
\hline & 1981 & 1991 \\
\hline Do 18 měsíců & $80 \%$ & $70 \%$ \\
Nad 4 roky & $3 \%$ & $8 \%$ \\
\hline
\end{tabular}

Jerome H. Skolnick (1995: 23) uvádí, že zatímco ve státě Kalifornie ještě v roce 1984 činil podíl výdajů na vyšší školství $14 \%$ a na věznice $4 \%$, po deseti letech se poměr srovnal na $9: 9$. Odhady důsledků realizace trestní politiky podle pravidla „třikrát a dost" přinášejí čísla až neuvěřitelně vysoká $\mathrm{z}$ hlediska počtu doživotně uvězněných.

Díváme-li se na věc právě z hlediska penologických konsekvencí, pak T. Blomberg (1995b: 60) nabízí rekordní údaj, když poprvé v historii USA dosáhl počet uvězněných hranice milionu osob. Zatímco v roce 1983 činil podle Úřadu justiční statistiky počet uvězněných 187 na 100 tisíc obyvatel, v roce 1994 to bylo již 387 vězn̆ů na 100 tis. obyvatel. A to ještě statistiky nezahrnují občany držené ve vazbě. Také výdaje státního rozpočtu na tuto oblast působí hrozivě. To pochopitelně vede autory jako $\mathrm{N}$. Christieho (1993) k úvahám o neomezené expanzivitě amerického „průmyslu sociální kontroly“. Považovat toto vše za fikci a za pouhou hru čísel by ovšem bylo naivní a nezodpovědné.

\section{Možnosti validizace statistik}

Snaha o validizaci údajů tohoto druhu odstartovala zhruba v 80 . letech vlnu viktimizačních výzkumů, při nichž se metodami anonymního dotazování reprezentativních vzorků veřejnosti zjišt'uje skutečný rozsah míry zasažení populace trestnou činností. Tyto výzkumy samozřejmě potvrdily předpoklad o existenci latentní, tedy nehlášené a nezaregistrované trestné činnosti, a také údaje o růstu viktimizace.

Elementární důvěryhodnost statistik doložily údaje o struktuře trestné činnosti, když v Británii (a také v současné době u nás, viz Buriánek 1997) byla zjištěna sku- 
tečně značná míra shody. Existují ovšem také některé typické rozdíly: v dotazníkových šetřeních se častěji objevují prípady vandalismu nebo hrozby agrese, naopak prakticky mizivá je šance tímto způsobem indikovat třeba zpronevěry, finanční podvody, apod. (Mayhewová a Hough 1991). Metodologické obtiže přináší i zjištování některých násilných trestných činů, znásilnění, zneužíváni či týrání dětí v rodině atd. (Zaubermannová 1991).

Posledním pokusem o doplnění informací pak jsou výzkumy založené na metodice self-reportu, kdy zkoumané osoby mají samy přiznat přestupky, které spáchaly. Jistý respekt vzbudily zatím výzkumy v oblasti delikvence mládeže, u běžné populace maji údaje tohoto druhu význam pouze orientační. Podle našich zkušeností lidé v rozhovorech uvádějí nejspíše tak ježdění načerno v dopravních prostředcích. V našich nejnovějších výzkumech proto zkoušíme položky další, přičemž mnohé by bylo možno dosáhnout i kombinací technik (anonymní poštovní ankety, prípadně telefonické dotazování). Existují také možnosti zpřesnění metody odhadu použitím sofistikovanějších statistických modelů.

Interpretativní sociologie by zřejmě ve všech případech namítala, že jde o konstrukce problematické výpovědní hodnoty, a to již ze sémantického hlediska (ve smyslu pojetí „normálního“ v každodenním životě: reálný problém tohoto druhu představuje výzkum sexuálního obtěžování, srovnej např. Buriánek 1996). Jestliže však ke stejným konstrukcím dospívají jak státní úruedníci, tak nezávislí sociologové pracující různými metodami, jsou takové obavy liché. Navíc naše zkušenosti ukazují, že v tomto terénu se potýká s obtižemi i nasazení kvalitativních metod.

Viktimizační výzkumy svého času kupodivu mírně korigovaly rostoucí „morální paniku“", když na jejich základě na počátku 80. let propočítali Hough a Mayhewová pro Brity pravděpodobnost stát se obětí:

- napadení s důsledkem poranění jednou za 100 let

- ukradení rodinného auta jednou za 60 let

- vloupání do bytu jednou za 40 let

Zcela jednoznačně však potvrdily existenci neevidované kriminality, a tím také onoho nebezpečného trendu, který nebylo možno vyřešit cestou „velkého odmítnutí“.

\section{Praxeologizace diskurzu a polarizace politik}

Na podkladě zmíněných teoretických střetů vzniklo počátkem 70. let podhoubí pro nový, kritičtějši pohled na zločinnost i na bezpečnostní politiku státu. Takzvaná new criminology propagovaná novou generací mladých britských kriminologů se pokusila spojit nové pohledy interpretativní sociologie se sociálněkritickým prístupem neomarxistủ. Přikládala ovšem zásadní význam analytickému pohledu usilujícímu o explanaci príčin neblahého vývoje a nepodceňovala datovou základnu, spiše akcentovala specifičnost interpretace výsledků. Někteři autoři jí dnes vytýkají menší zájem o vlastní empirický výzkum (Haralambos, Holborn 1994) a v lecčems dokonce až eklektické úsilí o syntézu. Její primární význam spočivá podle našeho názoru v zahájení diskuse o směrech a východiscích praktické politiky. 
Od poloviny 70 . let se potom postupně etablovaly zhruba čtyři základní prístupy ke zločinnosti. Pro jejich odlišení využijeme přehledu Jocka Younga, který sice vyšel z líhně nové britské kriminologie a projevuje přirozenou tendenci „fandit“ právě této vývojové větvi, má však statut mezinárodní autority a jeho výklad je svým způsobem učebnicový (Young 1994). Pro naše prostředí má jeho klasifikace poněkud pikantní příchut', nebot' se opírá o polaritu levicového či pravicového př́stupu, resp. materialismu a idealismu. Nejde však o klasifikaci ideologickou, nýbrž po výtce metodologickou, koncepční. $Z$ jeho schématu, které přece jen vycházi více $z$ britské situace, tak trochu vypadává postmoderní uvažování, to však můžeme snadno napravit zařazením dalšího speciálního paragrafu.

Podle Younga krystalizovala zhruba od roku 1980 čtyři paradigmata pokoušející se o řešení etiologické krize:

1. levicový idealismus navazující na teorii labelingu,

2. nová administrativní kriminologie zachovávající tradici teorie kontroly,

3. pravicový realismus reprezentující neopozitivistickou linii a

4. levicový realismus, $\mathrm{k}$ jehož zdrojům se řadí teorie subkultury.

Pro všechny varianty je typické hledání nového přistupu v porovnání $\mathrm{s}$ klasickým i pozitivistickým obdobím vývoje kriminologie: objevuje se snaha nepřeceňovat úlohu policie, a naopak využít více občanské, sociální kontroly, společné jsou i pochybnosti o funkčnosti systému vězeňství.

\section{Levicový idealismus}

Myšlení tohoto typu má nejbliže $\mathrm{k}$ neomarxismu, ale zasahuje i některé liberály. Velký vliv připisuje státu, prričemž jím sdílený sociální konstruktivismus zdưrazňuje prioritu administrativy nad strukturou (Young 1994: 81). Levicový idealismus bývá nezř́dka kombinován s kritikou rasismu nebo sexismu: přitom jeho vysvětlení, proč společnosti setrvávají v daném stavu nespravedlivé smlouvy vytvářející subkultury rezistence, spočivá v představě o institucionalizované dominantní ideologii, proti níž nelze úspěšně bojovat. Státní orgány se soustřed'ují na udržení řádu, rozšiřují sítě kontroly a provádějí labeling.

Autoři tohoto okruhu (např. S. Hall, 1978) se zabývali empirickým výzkumem kriminality ve vazbě na chudobu či nezaměstnanost, jakkoli poukazují na její existenci ve všech vrstvách. Proslavili se některými vyostřenými formulacemi, jako např. „obžalováním chudých za zločinnost je nakonec obžalujeme za jejich chudobu" (Ryan) nebo př́mo titulkem „Bohatí zbohatnou a chudé zavřeme" (J. Reiman). Poukazují na to, že stát vlastně využívá morální paniky šířené médii $\mathrm{k}$ posílení represivní moci.

Jejich kritikové jim ovšem neméně dưrazně připomínají, že korelace nezaměstnanosti a počtu uvězněných neobjasňuje skutečné prǐ̌činy kriminality, stejně jako expanze systému kontroly může být pouhou reakcí na rủst kriminality. Sociální determinace se projevuje specificky u jednotlivých druhů trestné činnosti a nadto lze ukázat, že viktimizace je často vnitrotř́dní, že tedy neplatí jánošíkovská legenda „bohatým brát a chudým dávat". Konstruktivismus se tak koncentruje pouze na stát a jeho institucionální mocenské aspekty, na druhé straně se opomiji třeba i biologická determinace zločinu. 


\section{Nová administrativni kriminologie}

Tento směr bere růst zločinnosti jako fakt, u něhož znalost příčin tolik nerozhoduje: za základ úspěšného boje se bere sociální kontrola s důrazem na kalkulaci př́ležitosti a rizika. V tomto smyslu - např. u Rona Clarka - využívá inspirace ze strany teorie racionální volby (viz též Garland 1995: 191). Počítá ovšem raději s omezenou racionalitou, s omezenou možností lidí získat informace. Nesouhlasí s nadměrnou patologizací zločinu, nemi̊že ovšem vyloučit ani situační propojení racionálních a iracionálních stránek.

Původní ideje teorie kontroly Travise Hirschiho (1969) zdůrazňovaly v hobbesovské tradici, že lidé páchaji trestnou činnost, když nejsou omezováni. Cílem společnosti tedy má být zločinnosti zabránit, ovšem s ohledem na motivaci aktéra, která nemusí být vždy př́liš silná či vyhraněná. Pro Clarka dokonce nebylo bezpodmínečně nutné poznat prričiny, aby byla prevence účinná: podobně jako fungují umělé hupy (retardéry) na silnici před křižovatkou, působí i jiná omezení príležitosti, využívání lepších bezpečnostních opatření, zámki̊ apod. $\mathrm{K}$ tomu všemu přispívá také aktivizace komunity, sousedské hlídky, ochota svědčit.

Ve vztahu $\mathrm{k}$ veřejnosti se projevuje přirozená snaha rozptýlit její obavy: slouži $\mathrm{k}$ tomu mimo jiné poznatek, že typická obět' se př́liš neliší od obrazu pachatele. Tím se vztah pachatele a oběti „morálně symetrizuje“ (Young 1994: 94). Young se vyhýbá označení pravicový idealismus, je však zřejmé přinejmenším to, že tento přistup př́sluší stávajícímu - v daném kontextu britskému - establishmetu.

\section{Pravicový realismus}

Pravicový realismus má svého vlivného představitele $\mathrm{v}$ J. Q. Wilsonovi, který byl svého času poradcem prezidenta Reagana a proslavil se knihou Thinking About Crime (1975). Jeho pravicové myšlení se ovšem neztotožňuje ani s liberalismem, ani $\mathrm{s}$ konzervativismem. Vrací se $\mathrm{k}$ některým myšlenkám pozitivismu a zdůrazn̆uje interiorizaci norem v dětství, nepřeceňuje efekty racionálního odstrašování.

Jeho pojetí vývoje zločinnosti je multifaktoriální, nebot':

- demografický vývoj určuje podíl „rizikových“ mladých mužů,

- mění se bilance zisků a ztrát v souvislosti se zločinem (pro některé jedince či skupiny je hrozba určitého trestu - např, vyloučení ze školy - př́liš vysokou daní),

- šire sociokulturních změn formou internalizované sebekontroly ovlivňuje schopnost rizikových jedinci̊ „odložit gratifikaci“ a dodržovat pravidla.

Wilson si nedělá iluze o možnostech změn základních parametrů, tj. demografického vývoje, stavu rodiny jako základní instituce, individualistického zaměření kultury, efektivity práce policie atd.. Je spiše pro dílčí změny bez zbytečného plýtvání prostředky, čemuž má sloužit i př́sná evaluace všech pokusů o řešení. Důraz na statistickou analýzu sbližuje americké realisty s britskými „administrativisty“ typu R.Clarka.

Úloha policie spočívá podle Wilsona nejen $\mathrm{v}$ kontrole, ale především ve facilitaci procesů sloužících zachování rádu. Jde o to, aby v komunitě nebyl narušen řád za hra- 
nici, odkud již není návratu. Autor tvrdí, že opilství na veřejnosti nebo pouliční prostituce může rozložit komunitu rychleji než jakýkoli tým profesionálních lupičů, z toho pak logicky vyplývá i jeho odpor ke snahám o dekriminalizaci tzv. zločinu bez oběti (prostituce, hrášství).

Ke slabinám tohoto prístupu patř́ celková akcentace řádu nad spravedlností (Young 1994: 102), Wilson uvažuje spíše o sociální kontrole než o odstranění sociální deprivace a naznačuje jistou toleranci vůči př́padnému narušení liberálních práv a procesních pravidel, nejsou mu proti mysli ani vysoké rozsudky nad recidivisty.

\section{Levicový realismus}

Jock Young sám datuje vznik tohoto směru (patři $\mathrm{k}$ němu ještě John Lea, Roger Matthew, Richard Kinsey) do počátku 80. let. Usiluje o překonání parciality ostatních směrů, respektuje reálnost vývoje v tom, že i sílící strach lidí ze zločinu je skutečností, prǐčemž současně může být zneužívána snaha o kontrolu zločinu. Postuluje nutnost vědeckého přistupu, komplexního vysvětlení i střízlivého a efektivního vynakládání prostředků.

Young vidí zločin jako komplex sociálních vztahů, které působí společně, a to leckdy ve zvláštní symbióze (viz obr. 3). Málokdo prý uvažuje o tom, že ukradené věci musí někdo prodat a někdo koupit... Statistiky odrážejí nejen senzitivitu veřejnosti (či spiše celého systému), ale také rostoucí násilí. Young se prriklání k názoru, že antisociální chování roste a tolerance klesá, prípomíná v tomto kontextu i Eliasův civilizační faktor (Young 1994: 105, viz též van Dijk, 1985). Připouští dokonce, že i to, co se jeví ve výzkumech viktimizace jako iracionální (např. vysoká míra obav ze zločinu u žen či starých lidí), může reagovat na něco spíše neviditelného.

Obr. 3 - Sociální kontext zločinnosti podle J. Younga

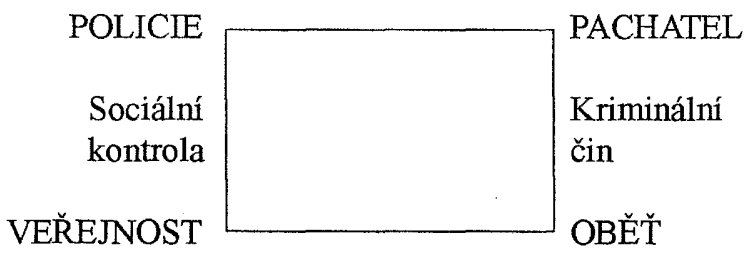

Zločin je považován za morální volbu v měnících se okolnostech, není to striktně determinovaná patologie, nýbrž vyjadřuje sociální organizaci i dezorganizaci. Má významné prostorové dimenze (včetně mezinárodních). Některé formy jsou svým způsobem konsenzuální (např. drogy). Základní př̌činy jsou hledány v relativní sociální deprivaci (srovnej Lea a Young in Muncie 1996: 136), v marginalizaci některých skupin. Tudy by se pak měla ubírat i prevence.

Na druhé straně leví realisté neupřednostňují monokauzální výklad: Young či Taylor spatřují motivaci ke zločinu i ve snaze o nadlepšení životního stylu, o statusové 
hodnoty. Zločin přestává být „monopolem chudých“ (Young 1994: 108). Tito autoři tedy oživují Durkheimovy představy o strukturních tlacích a o solidaritě, kritizuji ovšem nadměrná očekávání veřejnosti ve vztahu k péči státu. Na funkcionální linii navazují také představou o zločinu jako formě subkulturní adaptace. Motivy konstruktivismu spojují s otázkami moci - např. užívání drog je interpretováno z pozic potřeb subkultury, která může být dále stigmatizována reakcí moci.

Levicoví realisté by $\mathrm{v}$ konečné instanci dávali přednost spravedlnosti před řádem: zdůrazňují také úlohu komunity, jsou ale proti nadměrnému obtěžování občanů policií a proti porušování procedurálních pravidel v zájmu rychlého obnovení pořádku. Otevřeně se hlásí $\mathrm{k}$ tezi o korektivní roli sociálnědemokratické politiky ve vztahu $\mathrm{k}$ sociální deprivaci, přičemž dávají tuto okolnost do protikladu s vývojem v USA. To je samozřejmě námět $\mathrm{k}$ diskusi: $\mathrm{v}$ této interpretaci by bylo nutno považovat evropský model za modernější, nebo přinejmenším za sofistikovanější, což se jeví jako krajně odvážné. Na druhé straně Young sám usiluje o to, aby ukázal jistou komplementárnost Wilsonova př́stupu s idejemi poválečných britských socialisti̊, přičemž vnímá osudovou složitost kontrapozice účinná sociální kontrola versus zachování individuálních práv a svobod občanů (Young 1994: 117).

Více než celkem cudně deklarované politické sympatie je však pro nás koneckonců důležitější metodologická orientace tohoto směru. Zdůrazňovaný multifaktoriální purístup se projevuje i ve výkladu mechanismu, jehož působení vede za určitých okolností ke zhrouceni politiky vưči ohrožené komunitě, nebot' nabývá charakteru bludného kruhu (obr. 4).

Obr. 4 - Bludný kruh devastace komunity deterenční politikou

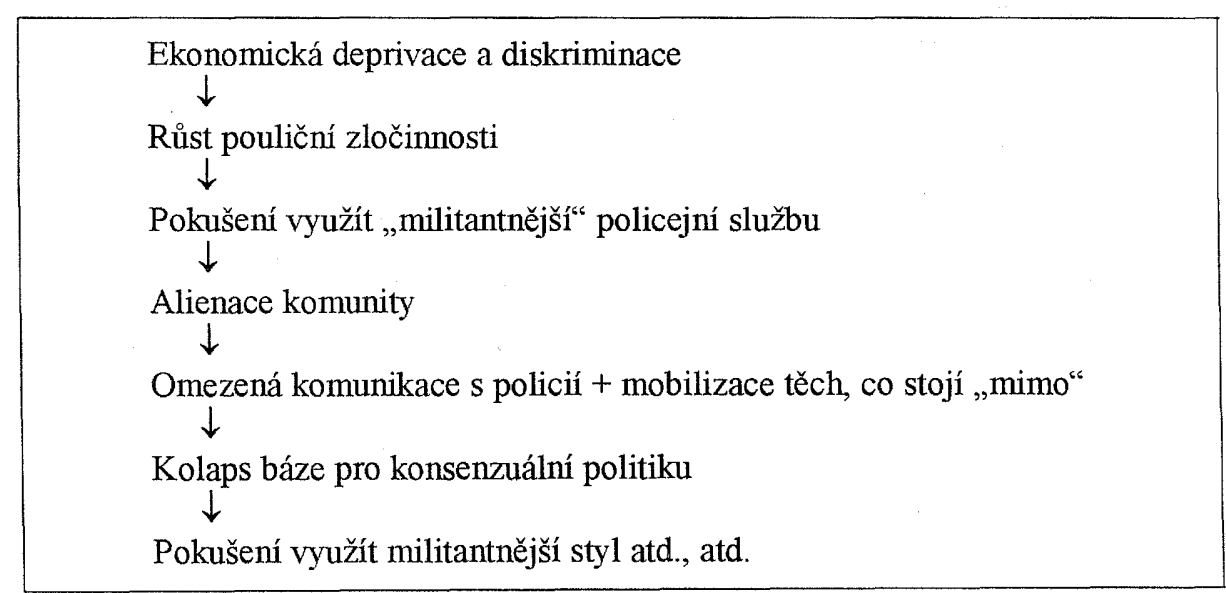

Levicový realismus se zrodil z nové kriminologie, která chtěla založit komplexní teorii deviace na spojení několika principů, prričemž akcentovala potřebu studia:

- distribuce moci a majetku ve společnosti

- významu deviantního aktu a reakce okolí 
- strukturálního vysvětlení reakce

- procesů labelování.

I když proklamovaná komplexnost a syntetičnost přistupu budí sympatie, nechrání přislušníky zmíněného směru před kritikou. Bývá jím vyčítáno nedostatečné objasňování přččin a absence výzkumu, až př́liš strukturalistické nebo subkulturní vysvětlení a v neposlední řadě $\mathrm{i}$ to, že se nezabývají podrobněji organizovaným zločinem a úlohou korporací (srovnej Haralambos, Holborn 1995: 430an).

A. Gouldner svého času oceňoval nástup nové kriminologie jako šanci provozovat tuto disciplínu nejen profesionálně, ale též jako intelektuální záležitost. David Nelken jako představitel soudobé reflexivní kriminologie ovšem komentuje s despektem právě to, že se z nových kriminologů stali do dnešní doby realisté (Nelken 1994: 2). Vyčíá jim jakýsi krok stranou od myšlenek konstruktivismu za cenu „teoretického populismu“" (tamtéž, s. 8).

Důraz na veřejný konsenzus prý přpomíná Foucaultovu disciplinaci, a proto se D. Nelken provokativně táže: „Je 'kriminolog' heterosexuálně orientovaným a anglicky mluvícím mužským přislušníkem střední trídy?“ Je záhodno uvažovat o „imperialismu" americké kriminologie, či naopak o lokálnosti kriminologického vědění? M. Pavarini k tomu připojuje další otázky: Mưže radikální kriminologie svobody někoho skutečně osvobodit? Anebo je větším rizikem přechod od Homo criminalis k Homo penalis, tedy člověku trestajícímu a trestanému (Pavarini in Nelken 1994: 45)?

Předmětem kritiky se stává dokonce sám ,strukturalistický" model levých realistů, kteři údajně „čtou ten kuplet očima oběti“ (Nelken 1994: 156). A jelikož zločin nerozlišuje tř́dy, lze $\mathrm{z}$ toho vyvodit, že $\mathrm{k}$ obětem patřime vlastně my všichni. Kritika $z$ reflexivních pozic poukazuje na často těžko předvídatelné proměny interpretace: jako ilustrativní př́lklad se zde nabízí změna rozsudku nad ženou, která v určité (pro ni zoufalé) situaci upálila svého muže. V procesu na ni bylo pohlíženo nejprve jako na vražedkyni, pak se z ní stala obět'. Realisté prý vidí město jako urbs (tzn. „kostky“), a ne jako civitas.

Levicový realismus zapadá do linie evropského kritického myšlení, které má i ve Spojených státech mnoho príznivců. Na druhé straně J.Young již dnes není revoltujícím mladíkem ani žádným démonem, ale excelentním, leckdy sžíravě ironickým a určitě ne nudným řečníkem, kterému akademická obec naslouchá s jistou dávkou obdivu. Z hlediska boje s kriminalitou (někteři "realisté“ ovšem raději mluví o její kontrole!) vystupuje kritický pohled jako celkem užitečný nástroj. Samozřejmě ani konzervativně laděných kriminologi̊ není v současné kriminologii zrovna málo a dokážou rovněž silně a „realisticky"argumentovat (viz např. empirické výzkumy Johna Hagana).

\section{Postmoderní reflexivní kriminologie}

Sociální konstruktivismus rozvijený $\mathrm{v} 60$. letech připravil půdu pro přijetí postmoderních koncepcí v kriminologii. Největší ohlas zaznamenalo dílo M. Foucaulta (1975), které bylo z velké části a opakovaně věnováno právě tematice deviace, 
zločinu a trestání. Kriminologie zaznamenala Lyotardem signalizovaný konec „velkých vyprávěni" a byla nucena brát na vědomí stanovisko, že intelektuálové již nejsou „legislativci“, nýbrž „interprety“ (Harvey, Jameson, Bauman). Začala se také vážně zabývat otázkou fragmentace.

Tezi o tom, že fragmentace ekonomická vede i ke kulturní diverzitě, rozkladu mravních zásad a růstu anomie, jí nabídl mimo jiné i R. Dahrendorf. Některé další sociologické inspirace zmíníme jen letmo, abychom mohli načrtnout obraz nové situace. Podle A. Giddense se postmoderní rád štěpí na množství kontextů jednání a forem autority, pł̌ičemž národní stát ztrácí na významu a kohezivní totalita je nahrazena multiplicitou stránek společenské reprodukce. V duchu velmi populárního tvrzení G. Therborna se tř́dní struktura lomí na dvoutřetinovou většinu a zbytek, který se stává objektem sociální politiky, přičemž je stále širší a odcizenější (srovnej též Keller 1995).

\section{Filozofická kritika modernity ve vztahu ke zločinu}

M. Foucault přispěl podstatným způsobem $\mathrm{k}$ destrukci mýtu racionality, přičemž naznačil spojení Rozumu s mocí (Volek 1994: 48). Jeho známé historické analýzy šílenství odkryly mechanismy sociální produkce tohoto jevu a otevřely problém kulturního relativismu, ovšem se značnou epistemologickou naléhavostí. Původní funkcionální jednota rozumu a nerozumu byla $v$ moderní společnosti definitivně narušena procesy industrializace, disciplinace a normalizace. To se projevilo internalizací sebekontroly, jakousi vnitřní autocenzurou, s níž operuje moderní psychiatrie. $K$ hlubšímu pochopení těchto tendencí Foucaultovi slouží analýza jazyka, sémantiky a dialogu (resp. mlčení), zkrátka diskurzu.

V této souvislosti sehrává významnou roli také fenomén moci. Jako mocenský nástroj vystupuje právě vědění, které se stává zdrojem kontroly. V současnosti dochází podle Foucaulta ke zvláštnímu konstruování subjektu cestami fragmentarizace, kategorizace a disciplinace, jde o jakousi individualizující taktiku společnosti na cestě $\mathrm{k}$ řádu. Za př́klad síly disciplinační moci bývá brán Benthamův projekt Panopticonu, ideálního kruhově konstruovaného vězení, kde si nikdo nemohl být jistý, že není pozorován. Foucault upozornil na problém organizované exkluze a na rafinované techniky disciplinace s tím spojené: menší pozornost arcit' věnoval užití moci v podobě otevřeného násilí.

Postmoderni př́stup otevřel nové horizonty také v otázce normativity. Pro Baumana je důležité, že na dělbě práce založená fragmentarizace a byrokratizace ztěžuje možnost morální výpovědi, objevuje se pluralismus autority na pozadí „kakofonie morálních hlasư“" (srovnej Müller 1994: 150). K přece jen optimističtějším závěrům vede přistup N. Luhmanna, u něhož tzv. dvojí kontingence propojuje individuální jednání $s$ nadosobní situací. V nejisté situaci oba účastníci interakce nakonec volí (kvưli hrozící destrukci) méně rizikové strategie, takže nakonec je možné reprodukovat rád i na bázi individuální autonomie. Bauman ovšem zdůrazn̆uje, že v masmediálním světě se vše mění v kaleidoskop epizod nebo karnevalových her, které podle Baudrillarda mohou vytvářet virtuální realitu (srovnej Nelken 1994: 11). Vyplývá z toho, že normy (stejně jako anomii a deviaci) je třeba vskutku interpretovat, a to velice opatrně. Pro- 
jevuje se zde strach z ideologizace, ze zneužití moci (viz např. historická zkušenost holocaustu, kteři někteří považují za „konec“ modernity).

Deziluze $z$ modernity vyjadřuje Lyotardovo stanovisko, že poslední dvě století nám přinesla více teroru, než můžeme unést, a že jsme zaplatili více než dostatečnou cenu za „nostalgii části a celku“ (Morrison 1994: 145). Morrisonova „melancholie“ čerpá opět $\mathrm{z}$ Baudrillarda, u něhož představuje základní tonalitu funkcionálních systémů díky ztrátě významů... (tamtéž, s. 135). Přitom již M. Weber poukazoval na lidskou „metafyzickou potřebu smysluplného kosmu“. Klasická kriminologie a pozitivismus se $\mathrm{v}$ tomto směru zcela samozrejmě jeví jako reprezentanti moderny ve smyslu metanarace sociální smlouvy nebo funkcionálního přirozeného řádu.

\section{Reflexivni kriminologie}

Je více než pravděpodobné, že právě tyto myšlenky vedly část kriminologů $\mathrm{k}$ hlubšímu zamyšlení nad stavem společnosti i své vlastní disciplíny (všimněme si, prosím, jak zlověstně zní právě ted' tento jinak běžně uživaný pojem!) . Rozčarování nad výsledky zmíněného sociálněinženýrského konstruktivismu, který lze tak trochu tušit i za polarizací kriminologického diskurzu v intencích Youngova výkladu, a dokonce určité obavy ze zneužití moderní racionality (zvláště ve spojení s politickou mocí) vedly $k$ aktivizaci reflexivního kritického myšlení. Šlo přitom o celou řadu praktických otázek:

- zda podléhá fragmentarizaci také kriminologie a jaké jsou její perspektivy,

- jak pojmout nově fenomény trestání a upevnění rádu,

- jak se vyrovnat s takovými tendencemi, jako jsou dekriminalizace trestné činnosti „bez oběti“, abolicionismus, ale také snaha o zpř́ísnění sankcí a o větší citlivost $\mathrm{k}$ některým trestným činům (např. v rodině),

- co dělat se zvýšenou citlivostí veřejnosti na bezpečnostní rizika (v rovině racionální i emocionální).

Představy o způsobu překonání fragmentarizace se samozrejmě liší. Pro někoho je důležitá její výstavba na pevném základě sociologie a jejích tradičních (z větší části pozitivisticky založených) metod výzkumu (J. Hagan), pro novou kriminologii zase na výše uvedeném systémově strukturním pohledu. S.Cohen by rovněž rád čerpal ze sociologie, ale tentokrát právě proto, že je silně reflexivní, že dokáže odhalit limity v jiných diskurzech (např. právním).

Reflexivní kriminologie se snaží důsledně oživit konstruktivistickou tradici, směřující leckdy až k G. H. Meadovi či ještě dál. Např́klad D. Melossi čerpá nejen ze Sutherlanda, ale také ze sociologické tradice simmelovské (pokud si všímá orientace jedince na určité sociální okruhy). Na jedné straně vidí akty konstituování sociálních objekti̊, symbolických obrazů společného neprítele, na straně druhé nepodceňuje strukturní souvislosti.

Aspekty sociálního postavení a reprodukce elit se promítají do praktické politiky často specifickým způsobem. Melossi poukazuje na italskou toleranci ke zločinu, pokud není ohrožena moc (1994: 212). „Úlohou reflexivní kriminologie je studovat celkovou komplexitu sociální atribuce krimálního labelu a trestu“" (Melossi 1994: 215). 
Nemá ale jít o redukci nebo o projekci problému do vztahu ke „státu“, na což poukázal již ve své teorii $\mathrm{D}$. Matza: deviant přirozeně chápe, že se stane předmětem zájmu Leviatana.

V otázce propojení teorie a praxe vede reflexivní sociologie diskusi s levicovými realisty, kteří kritizovali Cohenưv (1990) poukaz na ,žárlivého boha kriminologie“ a na konfliktní charakter rozhodování o jednotlivých prípadech. Skepticismus intelektuálů lze podle Cohena jen stěží skloubit s praktickými intervencemi, jež pak končí u morálního pragmatismu bez šance na předvídání důsledků takového jednání. „Reflexivní kriminologie není ani tak názvem pro nový teoretický př́stup ke kriminologii, jako spíše cestou $\mathrm{k}$ určení toho, co vstupuje do praktik teoretizování (Nelken 1994:30). Spíše tedy klade otázky, hledá opomenuté kontexty a nové cesty výzkumu. Prvořadý význam má otázka, zda bylo dosaženo dostatečně hluboké reflexe.

Reflexivní kriminologie se vztahuje $\mathbf{k}$ postmoderně dvojím způsobem. D. Nelken kupř́kladu rozlišuje mezi sociologii postmoderny(-ity) a postmoderní sociologií. Zatímco první proud uvažování rozvijí analýzu meritorních charakteristik soudobé společnosti, druhý směr je výrazněji profilován epistemologicky.

\section{Fragmentace a reflexivní modernizace}

V prvním okruhu nachází rexlexivní kriminologie mezi spřizněnými autoritami vedle Giddense či Baumana také U. Becka (1992) s jeho ideou reflexivní modernizace, když metodou kolonizace budoucnosti se stává vyhodnocování rizik v rámci společnosti, která je produkuje, a jejich veřejná kontrola. V tom se Beck shoduje i s J. Habermasem.

V situaci již zmíněné fragmentace skutečnosti bývá obvykle konstatováno, že soudobé instituce jsou různé a odlišně odpovídají na kriminalitu. Objevují se proto různé diskurzy (média, politika, ekonomie, věda, systémy pojištění), a to vše ve společnosti, v níž neustále roste sledování rizik a ochrana před nejistotou. Protože taková společnost je „vlastněna“ byrokraciemi, stává se, jak ř́ká Habermas, „posedlou“ procedurami. Lze to doložit vojenskou organizací policie nebo vyhlašováním „boje s drogami“.

Riziková společnost (Giddens, Beck) uplatňuje trojí logiku projevovanou v praxi různou měrou, ale pritom kombinovaně:

1. negativní logika konstruuje vhodné nepřátele (Christie 1986), užívá negativní labelling, odmítání, exkluzi. Solidarita společnosti potom vychází spiše ze strachu;

2. logika kontroly iracionality prostřednictvím racionálních prostředků: strach se stává základem racionálního jednání, lidé se obracejí na experty s otázkami, co dělat. Tak nahradila věda náboženství a došlo $\mathrm{k}$ „sekularizaci“ rizik, přičemž věda se stala rétorickou silou v politice rizik. Nic jiného se vlastně ani nedá vnímat, nebot' $\mathrm{z}$ této racionalizace rizik není vlastně úniku;

3. logika pojištění (insurance): pojem rizika je údajně neologismem pojištění, právě tahle instituce je základem racionalizace rizik. Riziko je objektivizováno jako nehoda, která je v principu propočitatelná. Produkuje konfigurace založené na partikulárních zájmech, které ale ovlivňují celky (hierarchii, solidaritu, spravedlnost viz Ericsen 1994: 103). 
Integrace moderní společnosti je tedy založena na strachu, na pokušení nahradit ekonomickou nerovnost distribucí a kontrolou rizik. Hodnoty nejisté společnosti tak dnes nahrazují dřivějš̌i hodnoty nerovné společnosti (Beck, Lau). Ohnisko zájmu se postupně přesouvá od osy „,deviace - kontrola - řád“ k „poznání - riziko - jistota“, labeling proto ztrácí na významu. Důsledkem toho je, že se policie se věnuje jen tomu, co s rizikem souvisí a co zajímá pojišt’ovny. I policie se stává expertem na riziko. „Neosobní komunikace a vliv médií způsobují, že se původně komunitní politika mění na komunikační politiku (Ericson 1993, podle Nelken: 104).“

Postmoderní př́stup se jak vidno může uplatnit i na velmi konkrétně vymezeném poli: lze se kupř́kladu i v reprezentativní britské učebnici (R. Reiner in Maguire 1994) setkat $\mathrm{s}$ názorem, že důraz na symbolickou funkci tamní policie jde tak trochu proti duchu doby a že její pojetí jako tělesa s „omnibusovým mandátem“, které plní celou raadu rozličných funkcí, nerespektuje fragmentarizaci a stává se anachronismem.

\section{Analýza diskurzu a nové pojetí zločinu}

Epistemologické pozice postmoderní sociologie nejsou běžně přijímány, panují obavy z dekonstrukčního nihilismu, který by znesnadnil propojení s veřejnou politikou. Kriminologie musí nalézt seriózní odpověd' třeba i na enormně rostoucí obavy ze zločinu (Nelken 1994: 17). K tomu však může posloužit i „konstruktivistický“ pohled - jako př́klad se připomíná studie o ne tak dávném únosu italského politika A.Mora. Objevují se proto analýzy diskurzu nebo rétorických struktur (Melossi, Henry a Milovanovic, Young a Rush): v kriminologii nemusí jít ani tak o texty, jako spíše o komunikaci, znaky nebo hry (spectacles).

Takzvaná konstitutivní verze postmodernismu chce propojit diskurz a praxi, strukturu a jednání (agency): u Hunta je zmíněná konstitutivní teorie chápána nikoli jako obsáhlá deskripce nebo jako formální model, ale jako provizorní metafora, jako způsob myšlení, jenž neproklamuje pravdu a je teorií bez záruky (Henry a Milovanovic 1994: 110). Není to tedy radikální dekonstrukce Derridova, nicméně na rozdíl od Hunta si Henry s Milovanovicem dokonce myslí, že v duchu „optimistického realismu“ je možné rozřešit „dekonstruktivní dilema“ (1994: 111).

Lidé jako aktivní činitelé kontinuálně i kontinuitně produkují svioj svět. Ne vždy to tak vnímají, většina je spíše „pacifikována“ (Matza) poměry. Dualita svobody a nutnosti se kombinuje s protikladem osobního zájmu a sociální spolupráce. Proto základem analýzy musí být linie ,jednání - diskurz - struktura“ (tamtéž, s. 113), usilující o identifikaci príslušných vzorců jednání či jazykových struktur.

Pro Teubnera (1992: 1451an) je také právo výsledkem procesu interdiskurzivity, kdy uvnitř organizace dochází nejprve $\mathrm{k}$ „produktivnímu nedorozumění, a poté reprođukuje sebe sama prostřednictvím norem. Legální pluralismus není konfliktem norem, ale množinou diverzních komunikačních procesů o tom, zda jednání je, či není legální. Definice zločinu je nyní považována za sociální konstrukci, to však neznamená, že všechny klasifikace můžeme považovat za fiktivní.

Zločin lze interpretovat jako moc odmítnout druhé, pričemž obět' je v tomto pohledu ničím. „Zákon je velmi dílčím seznamem škod,“ podotýkají k tomu Henry a Milo- 
vanovic (1994: 119). Vlastně všude je možno mocí poškozovat druhé. Nekritická oslava práva a z něj vycházející etiky často rekonstituuje existující mocenské vztahy. Uvedení autoři k tomu dodávají, že za určité konstelace se může docela klidně stát, že bezdomovectví bude zločinem.

Obr. 5 - Diskurzivní konstituce zločinu (upraveno dle Henry a Milovanovic 1994: 121)

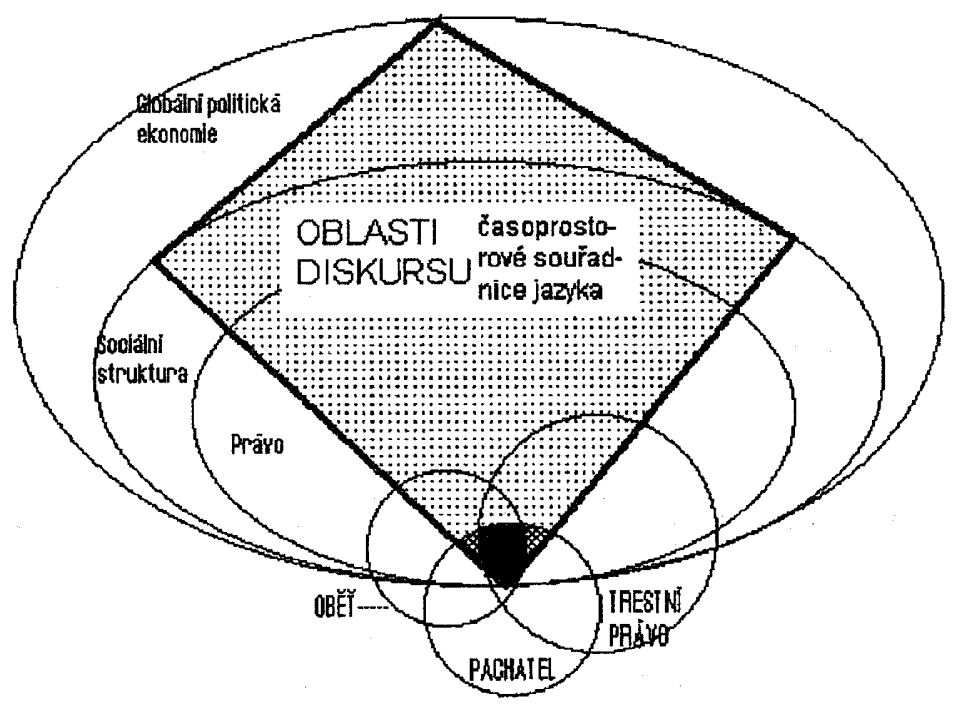

Zločin je „způsoben“ tím, že lidé ztratí vědomí humanity a integrity s tím, k němuž se vztahuji a koho se jednáním dotknou. Zločin je dialektickým procesem, který epizodicky dává lidem pocit, že jsou nezávislí na druhých (tamtéž, s. 123). Týká se to také korporací, potažmo státu.

Trestní politika vycházi obvykle z určité ideologie, př̌čemž musi dosáhnout jisté kontroly myšlení, mlčenlivého souhlasu. Snaha o maximální bezpečnost ovšem dnes vede $\mathrm{k}$ tipování, $\mathrm{k}$ výběru a ke sledování podezřelých. Radikální kriminologie to sice odmítá, leč podporuje ideologickou ochranu soukromí, a tím údajně legitimizuje likvidaci všeho společného. Centrální problém postmoderny definují citovaní autoři takto: ,jak dekonstruovat zločin a rekonstruovat to, co zločinem není?“ (Henry a Milovanovic 1994: 129). Anebo ještě jinak: Jak poskytnout právo odlišit se a nebýt odmítnut ostatními?

\section{Sociální kontrola a tzv. nová penologie}

Podle S. Cohena (1994: 67) může nabývat sociální kontrola čtyř forem: punitivni, kompenzační, konciliační (poradenské) a terapeutické. Současné trendy naznačují některé nové rysy, přičemž zčásti jde o př̌kročení úzce punitivního rámce:

1. expanze a intenzifikace kontroly;

2. moc profesionalizovaného vědění; 
3. manažerismus jako nové kolo ve hře na konec ideologie;

4. behaviorismus vedoucí $\mathrm{k}$ risk-managementu a kontrole populace, $\mathrm{v}$ jejímž rámci se využívají principy jako resocializace, racionální volba, situační prevence, proaktivní př́stup. Základem těchto úvah je „aktuární režim“ nebo „riziková společnost";

5. privatizace napojená na manažerismus dávající vznik celému průmyslovému odvětví privátních bezpečnostních služeb nebo terapeutické pomoci.

To vše je na mnoha místech planety navíc komplikováno procesem rychlých společenských přeměn, které mohou aktualizovat i zcela specifické formy trestání (např. lidové soudy, které v Jižní Africe svého času nahrazovaly justici). Cohen poznamenává, že $\mathrm{v}$ totalitních režimech zase lidé anticipovali nespravedlnost do rámce svých představ o právu (Cohen 1994: 78).

Termín actuarial justice použili v roce 1992 Malcom Feeley a Jonathan Simon. Předtím kralovaly pojmy jako jedinec, odpovědnost, povinnost, diagnóza, intervence, terapie: deviace byla chápána jako antisociální akt. Naopak tzv. nová penologie je radikálně odlišná, aktuární (aktuár jako pojištovací expert stanovuje rizika a plnění), využívá technik identifikace, klasifikace a ř́zení skupin tř́děných podle míry nebezpečnosti (Feeley a Simon 1994: 173). Deviace je už považována za normální jev, přičemž převažuje skepse vi̊či liberálnímu intervencionismu.

Základními principy této formy prosazení práva a trestání jsou:

1. oddělení zločince a selektivita vazby (incapacitation) - věznění je závislé spíše na kalkulaci rizika než na vážnosti činu;

2. preventivní detence - předprocesní rozhodování, selekce informací;

3. sestavování behaviorálních modelů (např̀. profily drogových kurýrů), podle nichž se hledají pachatelé.

Názory na reálné fungování principu proporcionality trestu jsou však dosud kontroverzní (srovnej D. Rothman, A. von Hirsch in Blomberg a Cohen 1995).

Jde také o to, zda nedochází $\mathrm{k}$ rozluce veřejného diskurzu setrvávajícího na pozicích „staré" penologie s profesionálním, který vychází z penologie nové. Simon a Feeley (1995: 147an) $\mathrm{k}$ tomu poznamenávají, že diskurz o trestání se proměňoval $\mathrm{z}$ polohy náboženské či ekonomické $\mathrm{k}$ psychologické a nakonec sociologické. Trvale byl totiž zdůrazňován vztah jedince a komunity. Jazyk nové penologie je však založen na systémové analýze a na aktuárním managementu rizik.

V minulém století byla cílem trestní politiky „náprava duše“, na počátku našeho lepší adjustace pachatele $\mathrm{v}$ komunitě. To $\mathrm{v}$ managementu rizik přestává platit: pohodlí se stává primární formou svědomí (Simon a Feeley 1995: 148).

Politika se zaměřuje na populaci, moc slouží minimalizaci rizika, justice je nahlížena nikoli jako racionální systém, ale „skrze racionalitu systému“ (Feeley a Simon 1994:178). Převládá význam hodnocení rizika recidivy, probace, parole (podmíněné propuštění, dohled). T. Blomberg (1995) v této souvislosti mluví o alternativě „rozdělení sankcí" (piling up sanctions). Normalizuje se ale také neustálé zastavování a prohližení lidí. Svou roli zde sehrál i systémový př́stup a operační výzkum, který pronikl mimo jiné i do armády USA v 60. letech. Souvisí to zcela zřetelně i s postojem společnosti $\mathrm{k}$ „underclass“, $\mathrm{k}$ „rizikovým skupinám“. 
Někteří autoři přitom značně neochotně přjímají označení alternativní tresty, protože:

- samo trestání podle zákona nelze považovat za „normální“ metodu sociální kontroly, je nanejvýš jednou z mnoha jejích dalších forem,

- „novéc formy dozoru a kontroly jsou mnohdy intruzivnější, techničtějš̌i a více všudyprítomné než dřivější (Blomberg a Cohen 1995: 9-10).

Nová pravice pritom směřuje od sociální verze aktuarismu ke zdůraznění privátní opatrnosti, nejde tu již o hodnoty a o akt hodnocení: volba je nahrazena povinností (např. u žen to může být kurs jak předcházet znásilnění...).

Feeley se Simonem si nekladou za cíl popsat zásadní historickou změnu, věnují se spiše historii současnosti a výše uvedené kritické poznámky k novému „modelu“ chápou jako výzvu, nikoli jako heuristický nástroj interpretace diskurzu i praxe (Simon a Feeley 1995:149). Pokud nový systém přináší některé úspěchy, měly by být adekvátně reflektovány i ve veřejném mínění. Jde tu o jistou kulturněnarativní stránku (D. Garland), o produkci jakési nové „pravdy o zločinu“. Jinak hrozí další vlna morální paniky a politické tlaky vedoucí $\mathrm{k}$ triumfu deterence a vyčlenění a $\mathrm{k}$ oslabení ideálů rehabilitace. Simon to naznačuje i podtitulkem jedné ze svých kapitol o postmoderní penologii: Moc bez narace.

S. Cohen nezpochybňuje názor levých realistů na užitečnost těch praktik, které se osvědčily. Nečiní si ale nejmenší iluze o samospasitelnosti participačních programů či občanské svépomoci, přeorganizovaného „zvládání rizik“, jež může snadno přerüst v karikaturu (srovnej S. Cohen in Muncie 1996). Jde mu zároveň o zachování svobody individua, tedy nikoliv o pouhou efektivitu systému, ale o spravedlnost (Cohen 1994: 85). Systémy sociální kontroly musejí samozřejmě fungovat na nejnižších úrovních, v rámci sociálních skupin. Cohen zde zavádí pojem „normativního rozvoje“ (success) ve smyslu jakési symbolické arény, $\mathrm{v}$ niž by byly objasňovány hodnotové volby. Preferuje pritom integraci před exkluzí, aktivní občanskou participaci, omezení moci profesionálních a byrokratických monopolu, demokratizaci uvnitř organizací atd.

David Garland (1995: 182) považuje S. Cohena spolu s Janem van Dijkem za jedny z prvních autorů, kteří užili termínu postmoderní k označení některých jevi̊ v kriminologii, a Feeleyho se Simonem za nejvýraznější představitele tohoto směru. Sám rekapituluje některé typické rysy moderního způsobu trestání:

- specializace tohoto systému a jeho relativní nezávislost na jiných normativních systémech,

- byrokratizace a profesionalizace systému,

- odklon od veřejných a symbolických forem, přesun „za scénu“,

- užívání peněžitých tresti̊ a dalších forem (probace ad.),

- jeho „průmyslový“ ráz vede ke vzniku profese kriminologa,

- navazuje na kulturní tradici osvícenství.

Fenomény přechodu spojuje s oslabením již zmíněného ( - moderního!) ideálu rehabilitace v 70 . letech a se snahou o zapojení komunity v letech osmdesátých (Scull, 
Cohen). Tu ovšem provázela diskuse o fungování nových sítí sociální kontroly (původní Cohenův předpoklad o jejich šíri a významu kritizovali McMahon nebo A. Bottom). Novou formou je nepochybně ostřejší diferenciace pachatelů. Důraz na racionalitu pachatele vede $\mathrm{k}$ tomu, že i v priběhu trestu je veden $\mathrm{k}$ osobní zodpovědnosti za další vývoj, objevují se ale také silněji retribuční aspekty diskurzu (Garland 1995: 192). Garland vidí přechodový moment ve vztahu k pragmatizaci a zpovrchnění kriminologického diskurzu, v čemž se svým způsobem shoduje s J. Youngem, a dále také s ohledem na fragmentarizaci (Ericson a Carriere 1994), k núž přsispivá také návrat biologických i ekonometrických modelů do kriminologie. $Z$ kontroly zločinnosti se často vytrácí morální rozměr a kontrolní systémy se jeví jako stále více autopoietické. Garlandovi se ale zároveň s tím jeví vášnivá a moralistní snaha o př́sné trestání jako antimoderní protipól administrativně racionálního př́stupu (Garland 1995: 202).

Přechod však nemůže být hodnocen jako jednoznačný a ostrý. I když v rámci „etiologické krize“ došlo ke zpochybnění možností kauzálního výkladu, usilují někteňí autoři i nadále o podobně zaměřené analýzy (J. Q. Wilson, R. J. Herrnstein: Crime and Human Nature: The Definite Study of the Causes of Crime, 1985). Garland rovněž poznamenává, že kdyby měla být kriminologie vycházející z teorie racionální volby považována za postmoderní, museli bychom takto označit i neoklasickou ekonomii nebo Benthamův utilitarianismus. Interní praktiky či techniky systému trestání se tolik nemění (cíle možná ano, ale instituce již nikoliv). Je též otázkou, zda snaha o přísný audit všech opatření neodpovídá spiše požadavkům modernity než postmodernity. Sebereflexivita moderních institucí zakládá možnosti jejích sebereformování, vědomí krize je předpokladem fungování ,tyranie sebepoznáni“. Jen nerealizované programy prý mohou být zdrojem optimismu, dodává trochu sarkasticky D.Garland (1995: 204).

\section{Místo závěru}

Z Garlandova shrnutí zretetelně vyplývá opatrnost při hodnocení jakési historické přelomovosti současné situace. Potvrzuje se, že ani reflexivní kriminologie či nová penologie neaspinují na označení postmoderní za každou cenu. Vycházejí z celkem stř́żlivého stanoviska, že každá, byt' markantní změna nemusí mít nutně epochální význam a nemusí znamenat popření dřive platných principů.

Garlandovy úvahy o postmodernismu v penologii nevykazují tak zřetelnou distanci od Youngova levicového realismu a jsou tolerantní i $\mathrm{k}$ dalším směrům, což je svým způsobem pochopitelné: Garland je profesorem University Edinburgh. „Světskée úvahy o kriminalitě možná nedosahují intelektuálního rozletu filozofických debat, přesto ale v konečném důsledku podle Garlanda napomáhají pochopení současnosti. Za důležité je třeba přitom považovat, že se námi zmíněná praxeologizace diskurzu prinnejmenším nedostává do opozice s principy postmoderny, lze-li to vůbec takto provokativně nanést.

Naznačené východisko se nám jeví jako atraktivní mimo jiné také proto, že by bylo zřejmě tak trochu nemístné vést prehledový článek k jakémukoli závěru. Naším zá- 
kladním cílem bylo poukázat na varietu prístupů $\mathrm{k}$ řešení problému, aniž bychom cítili potřebu klasifikovat je na moderní či postmoderní.

Namísto závěru tedy nabídneme reprodukci zcela obyčejného príběhu, který zažil jeden uznávaný odborník (Shearing in Muncie 1996) se svojí dcerou během návštěvy Disneylanđu. Tento zábavní park je charakterizován až úzkostlivou a všudypř́tomnou (samožrejmě stylově maskovanou) snahou nevystavit návštěvnúka riziku, dbát na jeho bezpečnost a zdraví. To vše se ukázalo jako problematické ve chvíli, kdy se dítku vytvořil puchýř na patě, prričemž ono chtělo - celkem logicky! -pokračovat dál bosky. To ovšem personál parku zásadně odmítl povolit, a postavil tak malou návštěvnici do situace obtižné volby: bud' pokračovat $\mathrm{v}$ tlačících botách, anebo ukončit prohlídku. Výsledek se dá snadno vytušit: vyhrál Disneyland se svou péči o zabránění rizikưm, jemu vlastní způsob disciplinace.

Nám sociologům pak v pozadí této takřka symbolické metafory o problému bezpeči v hypermoderni společnosti zůstává v hlavě jedna ne zcela př́jemná otázka $\mathrm{k}$ rozlousknutí: A co tomu všemu řeknou naše nohy?...

\section{Literatura}

BECK U.: Risikogesellschaft. Frankfurt am Main, Suhrkamp 1986

BECKER H. S.: Outsider's. New York, Free Press 1966

BLOMBERG T. G.: Beyond Metaphors: Penal Reform as Net-Widening. In: Blomberg T. G., Cohen S. (eds.): Punishment and Social Control. New Yor, Aldine de Gruyter 1995

BLOMBERG T. G., COHEN S. (eds.): Editorial Introduction. In: Punishment and Social Control. New Yor, Aldine de Gruyter 1995

BURIÁNEK J.: Systémová sociologie: problém operacionalizace. Praha, Karolinum 1994

BURIÁNEK J.: Sex (nejen) v rodinè. In: Sborník k 65. narozeninám doc. E. Urbánka, FF UK Praha, 1996

BURIÁNEK J.: Oběti trestné činnosti jako problém sociologického výzkumu a policejni praxe. Závěrečná zpráva, grant MV ČR, Praha 1997

COHEN S.: Visions of Social Control. Cambridge: Polity 1985

COHEN S.: Social control and politics of reconstruction. In: D. Nelken (ed.): The Futures of Criminology. London: SAGE 1994

DIJK J. J. M., van: Research and the victim movement in Europe. In: Research on victimisation. Council of Europe, Strasbourg 1985

ERICSEN R., CARRIERE K.: The fragmentation of criminology. In: D. Nelken (ed.): The Futures of Criminology. London: SAGE 1994

FEELEY M., SIMON J.: The Actuarial Justice: the Emerging New Criminal Law. In: D. Nelken (ed.): The Futures of Criminology. London: SAGE 1994

FOUCAULT M: Discipline and Punish: The Birth of Prison. London: Allen Unwin 1977

GARLAND D.: Penal Modernism and Postmodernism. In: Blomberg T.G., Cohen S. (eds.): Punishment and Social Control. New Yor, Aldine de Gruyter 1995

GIDDENS A.: The Consequences of Modernity. Cambridge: Polity 1990

HARALAMBOS M, HOLBORN M.: Sociology - Themes and Perspectives, 4. vyd. Collins Educational 1995

HENRY S., MILOVANOVIC D.: The Constitution of Constitutive Criminology: a Postmodern Approach to Criminological Theory. In: D. Nelken (ed.): The Futures of Criminology. London: SAGE 1994

CHRISTIE N.: Crime Control as Industry. London: Routledge 1993 
KABELE J.: Sociálni konstruktivismus, Sociologický časopis 32, 1996, č. 3

KELLER J.: Dvanáct omylu sociologie. Praha, SLON 1995

MAGUIRE M.: Crime Statistics, Patterns, and Trends: Changing Perceptions and their Implications. In: Maguire M. et al. (ed.): The Oxford Handbook of Criminology. Clarendon Press, Oxford 1994

MAYHEWOVÁ P., HOUGH, M.: The British Crime Survey: The First Ten Years. In: G. Kaiser, H. Kury, H. J. Albrecht (eds.): Victims and Criminal Justice. Victimological Research: Stocktaking and Prospects. Freiburg i. Br.: Max-Planck-Inst. 1991

MELOSSI D.: The 'Economy' of Illegalities: Normal crimes, Elites and Social Control in Comparative Analysis. In: D. Nelken (ed.): The Futures of Criminology. London: SAGE 1994

MUNCIE J. et al. (eds.): Criminological Perspectives. A Reader. London, SAGE Publ. 1996

MÜLLER V.: Normativni základy moderni společnosti v optice postmoderní kritiky. Sociologický časopis 30, 1994, č.2 (s.147-156)

NELKEN D.: Reflexive Criminology? In: D. Nelken (ed.): The Futures of Criminology. London: SAGE 1994

NOVOTNÝ O., ZAPLETAL J. (eds.): Základy kriminologie. Praha, PF UK 1996

SHEARING D. C., STENNING P. C.: From the Panopticon to Disney World: the development of discipline. In: Muncie J. et al. (eds.): Criminological Perspectives. A Reader. London, SAGE Publ. 1996

SIMON J., FEELEY M. M.: True Crime: The New Penology and Public Discourse on Crime. In. Blomberg T. G., Cohen S. (eds.): Punishment and Social Control. New Yor, Aldine de Gruyter 1995

SKOLNICK J. H.: Sheldon L. Messinger: The Man, His Work and The Carceral Society. In: Blomberg T. G., Cohen S. (eds.): Punishment and Social Control. New Yor, Aldine de Gruyter 1995

SUMNER C.: The Sociology of Deviance: An Obituary. Buckingham. Open Un. Press 1994

ŠUBRT J.: Modernizačni hesla a mýty v sociologii poválečné periody. Sociologický časopis 32 , 1996, č. 2

TAYLOR I.: The Political Economy of Crime. In: Maguire M. et al. (ed.): The Oxford Handbook of Criminology. Clarendon Press, Oxford 1994

TYLER T.: Why People Obey the Law. New Haven and London, Yale Un. Press, 1990

VOLEK J.: Pojem šilenstvi v kontextu dila Michela Foucaulta. Sborník prací filozofické fakulty Brněnské university, G 36, 1994

WILSON J. Q.: Thinking About Crime. 2. vyd. New York, Basic Books 1983

YOUNG J.: Incessant Chatter: Recent Paradigms in Criminology. In: Maguire M. et al. (ed.): The Oxford Handbook of Criminology. Clarendon Press, Oxford 1994

ZAUBERMANNOVÁ R.: Sources of information about victims and methodological problems in this field. In: Research on victimisation. Council of Europe, Strasbourg 1985

\section{On the Concept of Crime in Hyper-Modern Society}

\section{Summary}

In the Czech Republic the growth in crime since 1989 (by 1993 an increase of more then $300 \%$, followed by stabilization) has raised a series of questions recalling the recent "etiological crisis" (J. Young) of world criminology. Growing public fears have been stimulating what are often not very well founded discussions on practical policies, and the question of the quality of the statistics is always in the background. The aim of our survey article is to place these debates in a worldwide context and to note the experience (and the errors) accumulated in the sociology of deviation over the last 25 years. 
In our view, constructivism is a useful concept here, despite the fact that it has acquired various different meanings in the course of development:

1. Methodological constructivism as one of the standpoints in the dispute over method in the 1960 s (ethnomethodology, H. Becker, the critique of statistics from the stand points of radical criminology).

2. The social engineering connected with practical policies for the control of crime (the confrontation between conservative and liberal conceptions is in the background).

3. The constructivism inspired by post-modern thought (reflexive criminology, new penology)

The legacy of the constructivism of the 1960 s includes important ideas on the social definition of deviation and the principles of marginalization, exclusion and labelling. The critique of statistics has shown itself to be problematic, especially with respect'to research on victimization. This problem lends weight to realism (J. Young), emphasis on the empirical analysis of causes and strict evaluation of preventive programmes. Young's postulate of a systems-structural approach, and concern for social dynamics and phenomena of social deprivation, are also welcome. Some of the conclusions of the author of the article on further directions and particular research projects are related to this theme. The ideas of conservative sociologists on the role of socialization and normative consensus should not be underestimated, and the question of repressive measures and punishment then deserves special care.

When considering the possibilities for a more fundamental, if apparently in no way definitive solution to the problem of crime, we inevitably encounter the conception of modern society (M. Foucault). Postmodernism is in this context primarily a challenge to critical thought and the deepening of reflection. The new situation has been characterized by the concept of the risk society (U. Beck, A. Giddens), in which we see a changing approach to both prevention and punishment of crime. A new penology is emerging with the concept of actuarial justice (Feeley, Simon). The question of the effectiveness of punitive policy is posed. The attempt to gain a more profound understanding on the situation of criminology (T. Blomberg, S. Cohen, D. Mellossi) does not, of course, necessary entail a change in paradigm in the sense of the liquidation of the empirical basis of scientific understanding or an epistemological relativism. We see this, instead, as a mirror of practical policy. For this reason we also use the concept of the hyper-modern society and put the accent on the principle of reflexive thought: in the context of the ongoing modernization of Czech society, the attempt to modernize theoretical discourse, at least, is a pressing task and its importance should not be understated. 